\title{
Management practices to control gastrointestinal parasites in sheep farms in Minas Gerais, southeastern Brazil ${ }^{1}$
}

\author{
Aurora M.G. Gouveiaa, ${ }^{2,6}$, Marcelo B. Molento ${ }^{5,6}$, Marcos X. Silva $^{2,6}$, Humberto M. Brandão $0^{3,6}$, \\ Gabriela C. Gouveia ${ }^{2,6}$, Jorge B. Morlán ${ }^{4,6}$ and Alessandro S. Guimarães ${ }^{2,3,6 *}$
}

\begin{abstract}
Gouveia A.M.G., Molento M.B., Silva M.X., Brandão H.M., Gouveia G.C., Morlán J.B. \& Guimarães A.S. 2013. Management practices to control gastrointestinal parasites in sheep farms in Minas Gerais, southeastern Brazil. Pesquisa Veterinária Brasileira 33(4):464-468. Emprapa Gado de Leite, Rua Eugênio do Nascimento 610, Dom Bosco, Juiz de Fora, MG 36038-330, Brazil. E-mail: alessandro.guimaraes@embrapa.br

Parasite related problems are considered one of the major health problems for sheep breeding, causing considerable economic losses to commercial husbandry. The aim of this study was to determine the technological level and the level of knowledge of farmers regarding management practices to control gastrointestinal parasites in sheep in Minas Gerais state, southeastern Brazil. The analysis was based on 213 questionnaires applied by official veterinarians of the State Government Agency for Animal Health (Instituto Mineiro de Agropecuária, IMA), covering $16.6 \%$ of all counties. From two hundred and thirteen sheep farms sampled, 117 farms had their technological level determined. From the samples, $0.9 \%$ were characterized as high level, $45.3 \%$ as medium, and $53.0 \%$ as low technological level. The flock size ranged from 2 to 1843 with an average of 80.5 sheep per farm. The majority of the sheep production systems was extensive/semi-extensive (74.5\%). The management practices adopted by the farmers to reduce parasitism were: split young and adult animals (5.6\%), change pasture after deworm the animals (5.2\%), use quarantine for incoming animals (2.3\%), deworm newly arrived sheep (1.5\%), and have regular technical assistance (31.9\%). Although $76.5 \%$ of the farmers medicate the animals, treatments were performed without any major technical criteria, with an average interval of 4.6 months. The most commonly used drug families were macrocyclic lactones (38.5\%) and benzimidazoles (24.9\%). The management practices adopted in Minas Gerais are based on old recommendations and may not return in a good set of strategies to prevent parasite infections. Field observations reinforce the finding where farmers have obtained unsatisfactory results in maintaining the health and productivity level of their enterprises.
\end{abstract}

INDEX TERMS: Gastrointestinal parasites, sheep, control, technological level, epidemiological aspects, Minas Gerais, Brazil.

\footnotetext{
${ }^{1}$ Received on February 21, 2013.

Accepted for publication on March 15, 2013.

${ }^{2}$ Laboratório de Sanidade de Ovinos e Caprinos, Departamento de Medicina Veterinária Preventiva, Escola de Veterinária, Universidade Federal de Minas Gerais (UFMG), Cx. Postal 567, Av. Antônio Carlos 6627, Belo Horizonte, MG 31270-901, Brazil.

${ }^{3}$ Embrapa Gado de Leite, Rua Eugênio do Nascimento 610, Juiz de Fora, MG 36038-330, Brazil. *Corresponding author: alessandro.guimaraes@ embrapa.br

${ }^{4}$ Secretariado Uruguayo de la Lana, Sul, Montevideo, Uruguai.

${ }^{5}$ Laboratório de Doenças Parasitárias, Universidade Federal do Paraná (UFPR), Rua Quinze de Novembro 1299, Curitiba, PR 80060-000, Brazil.

${ }^{6}$ Grupo de Extensão da Pesquisa em Ovinos e Caprinos (GEPOC), Cx. Postal 567, Av. Antônio Carlos 6627, Horizonte, MG 31270-901, Brazil.
}

RESUMO.- [Práticas de manejo para controle de parasitas gastrointestinais em fazendas com ovinos em Minas Gerais, Sudeste do Brasil.] Problemas relacionados com parasitas são considerados um dos principais problemas sanitários na criação de ovinos, causando consideráveis perdas econômicas para criação comercial. 0 objetivo deste estudo foi determinar o nível tecnológico e o nível de conhecimento dos criadores sobre práticas de manejo para o controle de parasitas gastrintestinais em ovinos no estado de Minas Gerais, sudeste do Brasil. A análise foi baseada em 213 questionários aplicados pelos veterinários oficiais da Agência de Governo Estudal de Saúde Animal (Instituto Mineiro de Agropecuária, IMA), cobrindo 16,6\% de todos 
os municípios. Duzentos e treze propriedades com ovinos foram amostradas e 117 tiveram o seu nível tecnológico determinado. A partir da amostra, $0,9 \%$ foi caracterizado como nível elevado, de 45,3\%, como de médio e 53,0\% como baixo nível tecnológico. 0 tamanho do rebanho variou de 2 a 1843 com uma média de 80,5 ovinos por propriedade. A maioria dos sistemas de produção de ovinos eram extensivos/semi-extensivos (74,5\%). As práticas de manejo adotadas pelos criadores para reduzir o parasitismo foram: separar animais jovens e adultos $(5,6 \%)$, mudança de pastagem após vermifugar os animais $(5,2 \%)$, uso de quarentena para animais recem adiquiridos $(2,3 \%)$, vermifugação de ovelhas recém-chegadas $(1,5 \%)$ e assistência técnica regular (31,9\%). Apesar de 76,5\% dos criadores vermifugarem os animais, os tratamentos foram realizados sem qualquer critério técnico importante, com um intervalo médio de 4,6 meses. As famílias de drogas mais comumente usadas foram lactonas macrocíclicas $(38,5 \%)$ e benzimidazóis $(24,9 \%)$. As práticas de manejo adotadas em Minas Gerais são baseadas em recomendações antigas e não em estratégias para prevenir infecções parasitárias. As observações de campo reforçam os achados em que os proprietários obtiveram resultados insatisfatórios na manutenção dos níveis de saúde e produtividade de seus empreendimentos.

TERMOS DE INDEXAÇÃO: Parasitas gastrointestinais, ovinos, controle, nível tecnológico, aspectos epidemiologicos, Minas Gerais, Brasil.

\section{INTRODUCTION}

Gastrointestinal nematode parasites constitute an important factor of economic losses for sheep production. All age groups are affected by gastrointestinal helminths, but the categories at major risk are lambs and pregnant ewes (Gennari \& Amarante 2006). The presence of parasites, however, is not synonymous of parasitism once the animals in flocks raised in suitable conditions can have infected animals in good health without the intense use of antiparasitic drugs (Molento et al. 2009). Thus, host immune mechanis$\mathrm{ms}$, in most cases, are able to keep the parasite population under control (Guimarães et al. 2011).

The resistance to anthelmintic drugs has become a serious problem in countries where small ruminants' husbandry is important. Chemical control of parasitic diseases is widely employed in Brazil (Depner et al. 2007) and multiple-drug resistant nematodes have been reported worldwide (Van Wyk et al. 1997, Besier \& Love 2003, Kaplan et al. 2004, Melo \& Bevilaqua 2005) to the extent that total anthelmintic failure is seen as a real possibility in some situations. Prevalence was recorded in a fecal egg count (FEC) survey in Brazil of $23.6 \%$ of predominantly Haemonchus spp. resistant to moxidectin (Thomaz-Soccol et al. 2004). Torres-Acosta et al. (2012) reported a problematic situation in Latin America related to technology transfer and Molento et al. (2011) showed how the different control strategies are being implemented in this area. In 33 sheep flocks in the State of São Paulo, southeastern Brazil, $81.3 \%$ used quarantine to newly acquired animals,
$57.6 \%$ had technical assistance, $66.7 \%$ used anthelmintics regularly, $48.5 \%$ used the FAMACHA method, and 33.3\% used faecal egg count exams to monitore gastrointestinal parasites where macrocyclic lactones was the class of anthelmintics commonly used (Niciura et al. 2010). Direct consequences of these malpractices may also account for the increased cost of production, increased animal mortality, extensive chemical residues in milk, lamb meat, and in the environment.

The growth of the sheep population for meat production in Brazil began in the 2000's, from 14.7 millions in 2000 to 17.4 million in 2008 (IBGE 2010) representing an increase of $15.5 \%$. In the same period, the increase of sheep population in Minas Gerais has grown from 116.796 to 228.306 thousand animals, an increasing of $95.5 \%$, mostly for meat production (ANUALPEC 2008). Minas Gerais has the second largest sheep population of the four states in the southeastern region of Brazil (Guimarães et al. 2009).

In this context, the use of integrated management practices and strategic control of parasites that aim to rationalize parasite-host interaction and enable identification and selection of resilient animals are important, and may reduce selection pressure to anthelmintic resistance (Torres-Acosta \& Hoste 2008). This study aimed to determine the technology status and the level of knowledge of sheep farmers regarding endoparasites and the control strategies used in the state of Minas Gerais (MG), Southeastern Brazil.

\section{MATERIALS AND METHODS}

\section{Sampling area}

The study was conducted in twelve regions of MG, the state with the second biggest sheep population in the Southeastern region of Brazil (Fig.1). MG has a total area of 588,383 $\mathrm{km}^{2}$ and 853 counties, representing $15.5 \%$ of Brazil. The altitude ranges from 100 to 1500 meters. The predominant climate is mostly tropical with summer rains and the average annual temperature is $21.2^{\circ} \mathrm{C}$. Annual rainfall varies from $1000-2000 \mathrm{~mm}$ with well-defined dry and wet seasons (SEA 2008).

\section{Questionnaire to farmers, sampling and experimental design}

A questionnaire, prepared by the Sheep and Goat Extension and Research Group, has been previously tested (Magalhães \& Gouveia 1985, Pinheiro et al. 2000). Official Veterinarians applied the questionnaire in 2002. It was impossible to do random sampling because the absence of official registration of sheep breeders in the State, then, non-probabilistic sampling was used,

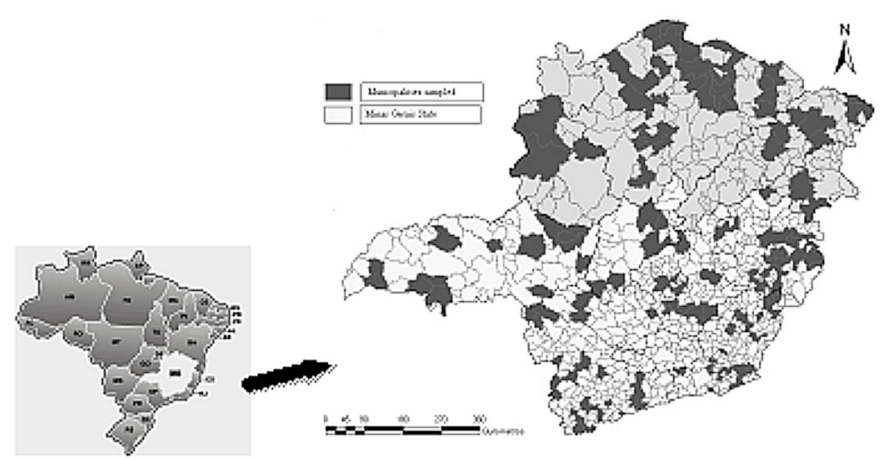

Fig.1. Counties with sheep farms where questionnaries were applied (dark patches) in Minas Gerais, Brazil. 
starting from the lists of sheep farmers registered at the IMA, Association of Sheep and Goat Producers of the State of Minas Gerais (Associação de Criadores de Caprinos e Ovinos do Estado de Minas Gerais, ACCOMIG) and the Technical Assistance and Rural Extension Company of Minas Gerais (Empresa de Assistência Técnica e Extensão Rural de Minas Gerais, EMATER). We sampled 213 sheep farms located in 142 municipalities of MG (Fig.1). The data were analyzed using the software Windows Excel 98 and Epi-Info (Dean et al. 1995) to establish the frequency of each variable in the samples collected. Comparison of frequencies was performed using the chi-square test.

\section{Determination of the technology status of the farms}

To determine the technological level on the farms, 13 variables were selected and scored (the score values are shown in parentheses) based on criteria used by Silva (2002) and Laender (2002). The variables related to "infrastructure" were: the use of animal housing ( 2 points), regular technical assistance by veterinarians ( 3 points), and manure composting or elevated floors (3 points). As for "nutritional status" were: the presence of high-quality pasture ( 2 points), the division of pasture (1 point) and the use of mineral supplements (1 point). As for "health": disinfection of newborn animals (1 point), deworming (1 point), some forms of diagnosis of diseases ( 3 points) and the use of vaccines ( 2 points) were considered and on the "production" the variables were: age at weaning ( 2 points), controlled breeding ( 3 points), and the use of breeding season ( 2 points). The technological level was obtained by dividing the points scored for each farm by the total possible points ( 26 points). The percentage obtained was used to classify the property according to the following cut-off values: low-technology level - farms with a percentage between 0 and 33\%, medium-technology level - those with a percentage between 34 and 64\%, and high-technology level - those with a percentage score above $65 \%$.

\section{RESULTS}

One hundred and seventeen farms had their technology level detersmined. A final farm score was not determined when two or more variables had no answer. High-technology farms were classified on only $0.9 \%(2 / 117), 45.3 \%$ $(53 / 117)$ of the farms were classified as medium level and $53.0 \%(62 / 117)$ as low level.

The number of sheep in each location ranged between 2 and 1843 with an average 80.5 and the area of the farms ranged between 1 and 1100 hectares (ha); with average 316.9ha. All the farms had meat-producing animals. Extensive farming was present in $42.2 \%\left(90 / 213^{\mathrm{a}}\right)$ of sampled farms, whereas semi-extensive system was determined in $32.9 \%\left(70 / 213^{\mathrm{a}}\right)$ and intensive in only $0.9 \%\left(2 / 213^{\mathrm{b}}\right)$. It was considered extensive farming when animals were raised exclusively on pasture, eventually protected from predators at night, but without supplementation during most of the year. The semi-extensive system was characterized by some supplementation, either during the rainy or dry season and the intensive system was considered when farms used no grazing, and the animals were confined $100 \%$ of the time.

Table 1 presents the management strategies in the sheep farms that may, directly or indirectly, affect endoparasitism.

Table 2 presents the frequency of the sheep farms based on anthelmintic use in the state of MG. The practice of me-
Table 1. Frequency distribution of 213 farms with sheep sampled in Minas Gerais, Brazil, concerning practices adopted that may affect endoparasitism ( $n=$ number of farms)

\begin{tabular}{lcc}
\hline \multicolumn{1}{c}{ Practice adopted } & $\mathrm{n}$ & $\%$ \\
\hline Separate young and adult animals & 12 & 5.6 \\
Change pasture after deworming & 11 & 5.2 \\
Use of quarantine for incoming animals & 5 & 2.3 \\
Use of anthelmintics for incoming animals & 31 & 1.5 \\
Yearly rotation of anthelmintic & 72 & 33,8 \\
Individual identification and herd records & 64 & 30.0 \\
Mix goats and sheep & 89 & 41.8 \\
Presence of technical assistance - regular & 68 & 31,9 \\
Not answered & 32 & 15.0
\end{tabular}

Table 2. Distribution frequency of 213 sheep properties based on anthelmintic use in the state of Minas Gerais, Brazil ( $n=$ number of farms)

\begin{tabular}{cccc}
\hline Variable & Answer & $\mathrm{n}^{*}$ & $\%$ \\
\hline Anthelmintic treatment & Yes & $163^{\mathrm{a}}$ & 76,5 \\
& No & $34^{\mathrm{b}}$ & 16,0 \\
& Not informed & 16 & 7,5 \\
Interval between treatments & Total & 213 & 100 \\
& $2.1-4$ months & $2^{\mathrm{a}}$ & 1.2 \\
& $>4.1$ months & $102^{\mathrm{b}}$ & 62,6 \\
& Not informed & 59 & 27,7 \\
& Total & 163 & 100
\end{tabular}

${ }^{*}$ Different letters in same column indicate significant differences $(\chi 2 ; \mathrm{p}<$ 0.05 ) between the strata formed on the same criterion.

Table 3. Distribution frequency of 213 farms in the state of Minas Gerais, Brazil, for the main chemical classes used for parasite control ( $n=$ number of farms)

\begin{tabular}{lcc}
\hline \multicolumn{1}{c}{ Chemical class } & $\mathrm{n}$ & $\%$ \\
\hline Macrocyclic lactones & 82 & 83.5 \\
Benzimidazoles & 53 & 24.9 \\
Imidatiazole & 7 & 3.3 \\
Organophosphorus & 5 & 2.3 \\
Piperazine & 0 & 0.0 \\
Not informed & 66 & 30.9
\end{tabular}

dicating the animals was predominant in the sampled and the average treatment interval was 4.6 months.

The chemical groups most frequently used are summarized in Table 3.

\section{DISCUSSION}

This is the first study reporting information from sheep far$\mathrm{ms}$, breeders and health status in Brazil. Ninety-eight point three percent of the farms presented medium- or low-technology level, consequence of the low frequency of use of good management practices, mainly for parasites control. According Guimarães et al. (2009), farms with low level of technology have high mortality rates, low frequency of technical assistance and productivity rates. Breeders are receptive when the benefits of sustainable animal production are obvious and the presence of anthelmintic resistance is usually not appreciated until severe production losses or clinical signs become evident (Van Wyk et al. 1997).

The farming systems did not show significant differences in MG mostly because of the predominant extensive/ 
semi-extensive production. The small flock size and farm area also indicates the family-based, small-scale agriculture systems, with the simultaneous raising of sheep and goats (Table 2), on the extensive system. It can be assumed that on extensive systems it is more difficult to control endoparasites infections due to the greater contamination during grazing, exacerbated by cohabitation of young and adult animals (Table 2). Farming in small areas, with permanent grazing and high stocking rates, predispose animals to helminth infection (Siqueira 1993) as seen on this system, where more than $95 \%$ of the parasite population was on pasture.

In this study, pasture rotation was important to the production systems and few breeders used to transfer the animals to another pasture after drenching, with the objective of delaying the onset of resistance, although Molento et al. (2004a) have reported not to move the animals after drenching. Moving the animals after treatment is a common practice, as noted from $39.4 \%$ of sheep farmers in São Paulo. Strategies to optimise the refugia population may involve leaving animals on helminth-contaminated pasture after drenching, or selecting some animals from a group not to be treated, in these situatons, the progeny of the worms that successfully resist treatment would be diluted by mating with unselected worms present on pasture.

Multidrug resistance parasites against imidothiazoles (Sangster 1999), benzimidazoles (Silvestre \& Cabaret 2002), and moxidectin (Blackhall et al., 1998), have been described in Brazil (Thomaz-Soccol et al. 2004). The spread of resistant parasites is also increased by the intensive interregional transit of sheep and goats. Sheep breeders of MG have been purchasing animals from the Northeast of Brazil, allowing the introduction of unkonwn parasites background. The limited use of quarantine for incoming animals in MG (Table 1) can exacerbate the situation allowing the introduction of different infectious agents such as helminths. According to Coles and Roush (1992), from the United Kingdom, the likelihood of spreading anthelmintic-resistant nematodes could increase with the purchase of animals from other regions. In state of São Paulo, 81.3\% of the sheep breeders used quarantine (Niciura et al. 2010) showing a significant difference regarding their level of information when compared to the present study.

Animals from the same flock may require different strategies or treatment schedule based on individual assessment, then, methods such as faecal egg count (FEC), are impractical due to limitations of cost and trained personnel (Van Wyk et al. 2006). The FAMACHA (Faffa Malan Chart) system may be used in short intervals, to identify resilient and more tolerant animals, which can support the damage effects of parasite infections, despite the great number of parasites and EPG values. Resilient animals can also maintain good body condition score and productivity (Molento et al. 2004b). The FAMACHA system is a valuable tool to resource-poor farmers in developing countries (Van Wyk et al. 2006).

Few farmers changed the anthelmintic class based on any technical guidelines and or the results from EPG. Frequent changes of anthelmintics may increase anthelmintic selection (Molento et al. 2011), whereas the continuous use of the same group is recommended with constant monitoring (Van Wyk et al. 2001). The strategic replacement of drug groups after monitoring may decrease the pressure on the homozygous resistant genes, delaying the process of selection of resistant parasites (Molento 2004). In this study, the treatment intervals were considered to be long, with no drug monitoring. Therefore, we confirm that the worm control based on the exclusive use of anthelmintics is doomed to failure.

Macrocyclic lactones (ML) were the most common class of anthelmintics in the farms and benzimidazoles (albendazol and febendazol) were the second most common group. The ML, mainly ivermectin, is widely used because of its broad-spectrum activity against internal and external parasites. On the other hand, benzimidazoles have an excellent spectrum against endoparasites. These drugs are alternatives on farms where resistance to ML is a problem, mainly in Haemonchus contortus (Leathwick et al. 2001).

Technical assistance, training of farm employees in good husbandry practices and the monitoring of parasite control programs for each farm is necessary. Niciura et al. (2010) found low level of technical assistance (57.6\%), demonstrating the need for increasing of the presence of technicians in other regions of the country as well as on sheep farms in MG. The complexity of recommendations to anthelmintic treatment with alternative systems suggests that in most countries the declining number of experts have little chance of successfully transferring the best technologies to the farmers. Then, the presence of regular technical assistance is essential to the success of sheep farming and can reduce all management failures.

\section{CONCLUSIONS}

The low-technology level and the lack of adoption of management practices in sheep farms was a common feature in Minas Gerais.

Sheep breeders still rely on the use of chemicals.

Sheep farmers worry about worm infections, but they use long intervals between deworming and rotate drugs without any technical support.

Therefore, there is need for strong technology-transfer programs to support good management practices in order to minimize the potential risk factors that contribute to the development of anthelmintic resistance.

Acknowledgments.- The authors wish to thank the farmers for their willingness to participate, the ACCOMIG Association for their support, and Instituto Mineiro de Agropecuária (IMA) and their veterinarians for conducting the interviews ANUALPEC. Financial support was provided by IMA and Fundação de Ensino e Pesquisa em Medicina Veterinária e Zootecnia (FEP-MVZ).

Conflict of interest statement.- The authors declare that they have no competing interests.

\section{REFERENCES}

ANUALPEC 2008. Anuário da Pecuária Brasileira. 1a ed. Instituto FNP, São Paulo.

Besier R.B. \& Love S.C.J. 2003. Anthelmintic resistance in sheep nematodes 
in Australia: the need for new approaches. Aust. J. Exp. Agric. 43:13831391.

Blackhall W.J., Pouliot J.F., Prichard R.K. \& Beech R.N. 1998. Haemonchus contortus: selection at a glutamate-gated chloride channel gene in ivermectin- and moxidectin-selected strains. Exp. Parasitol. 190:42-48.

Coles G.C. \& Roush R.T. 1992. Slowing the spread of anthelmintic-resistant nematodes of sheep and goats in the United Kingdom. Vet. Rec. 130:505510.

Dean A.G., Dean J.A., Burton A.H. \& Dicker R.C. 1995. EPIINFO, a word processing, date base and statistis program for epidemiology on microcomputers. Georgia: USD, version 6.02.

Depner R.A., Gavião A.A., Cecim M., Rocha R. \& Molento M.B. 2007. Desempenho de cordeiros naturalmente infectados com parasitas gastrintestinais utilizando o tratamento seletivo com o método FAMACHA e o tratamento preventivo. Arch. Vet. Sci. 11:32-37.

Gennari S.M. \& Amarante A.F.T. 2006. Helmintos de ovinos e caprinos. Biológico, São Paulo, 67:13-17.

Guimarães A.S., Gouveia A.M.G., Abreu C.P., Haddad J.P.A. \& Carmo F.B. 2009. Características zoossanitárias da ovinocultura em Minas Gerais. Revta Vet. Zootec. Minas 102:34-40.

Guimarães A.S., Gouveia A.M.G., Carmo F.B., Gouveia G.C., Silva M.X., Vieira L.S. \& Molento M.B. 2011. Management practices to control gastrointestinal parasites in dairy and beef goats in Minas Gerais, Brazil. Vet. Parasitol. 176:265-269.

IBGE 2010. Censo Agropecuário. Instituto Brasileiro de Geografia e Estatística. Online available at <www.ibge.gov.br> Accessed on May 10, 2012.

Kaplan R.M., Burke J.M., Terrill T.H., Miller J.E., Getz W.R., Mobini S., Valencia E., Williams M.J., Williamson L.H., Larsen M. \& Vatta A.F. 2004. Validation of the FAMACHA eye color chart for detecting clinical anaemia in sheep and goats on farms in southern United States. Vet. Parasitol. 123:105-120.

Laender J.O. 2002. Língua Azul em rebanhos de ovinos e caprinos em três mesorregiões de Minas Gerais: análise da evidência clínica e sorológica e identificação de Culicoides sp. Dissertação de Mestrado, Escola de Veterinária, Universidade Federal de Minas Gerais, Belo Horizonte, MG. 92p.

Leathwick D.M., Pomroy W.E. \& Heath A.C.G. 2001. Anthelmintic resistance in New Zealand-Riview. N. Z. Vet. J. 49:227-235.

Magalhães H.H. \& Gouveia A.M.G. 1985. Diagnóstico da situação da caprinocultura em algumas microrregiões dos Estados de Minas Gerais e Rio de Janeiro. Revta Cabra e Bodes 1:5-7.

Melo A.C.F.L. \& Bevilaqua C.M.L. 2005. Genetic approach of anthelmintic resistance in Haemonchus contortus. Revta Port. Ciênc. Vet. 100:141146.

Molento M.B. 2004. Resistência de helmintos em ovinos e caprinos. Revta Bras. Parasitol. Vet. 13:82-87.

Molento M.B., Van Wyk J.A. \& Coles G.C. 2004a. Sustainable worm management. Vet. Rec. 155:95-96.

Molento M.B., Tasca C., Gallo A., Ferreira M., Bononi R. \& Stecca E. 2004b. Método FAMACHA como parâmetro clínico individual de infecção por Haemonchus contortus em pequenos ruminantes. Ciência Rural 34: 1139-1145.

Molento M.B., Gavião A.A., Depner R.A. \& Pires C.C. 2009. Frequency of treatment and production performance using the FAMACHA method compared with preventive control in ewes. Vet. Parasitol. 162:314-319.

Molento M.B., Fortes F., Pondelek D., Borges F.A., Chagas A.C.S., Torres-Acosta J.F.J. \& Geldhof P. 2011. Challenges of nematode control in ruminants: Focus on Latin America. Vet. Parasitol. 180:126-132.

Niciura S.C.M., Veríssimo C.J., Molento M.B., Rodrigues C.F.C., Margatho L.F.F., Costa R.L.D. \& Curci V.C.L.M. 2010. Investigação do manejo e do controle de verminose em criações de ovinos no Estado de São Paulo. Comun. Téc., Embrapa Pecuária Sudeste, São Carlos, SP.

Pinheiro R.R., Gouveia A.M.G., Alves F.S.F. \& Haddad J.P.A. 2000. Aspectos epidemiológicos da caprinocultura cearense. Arq. Bras.Med. Vet. Zootec. 52:534-543

Sangster N.C. 1999. Pharmacology of antihelmintic resistance in cyathostomes: will it occur with the avermectin/milbemycin. Vet. Parasitol. 85:189-204.

SEA 2008. Zoneamento Agroclimático de Minas Gerais. Secretaria de Estado de Agricultura. Available at: www.geominas.mg.gov.br> Accessed on Jun. 12, 2012

Siqueira E.R. 1993. Produção de carne ovina. Proc. 6 Simpósio Paranaense de Ovinocultura, Maringá, p.1-14.

Silva M.X. 2002. Soroprevalência da Língua Azul em caprinos do Ceará, Brasil e sua associação com indicadores de tecnologia. Dissertação de Mestrado, Escola de Veterinária, Universidade Federal de Minas Gerais, Belo Horizonte, MG. 76p.

Silvestre A. \& Cabaret J. 2002. Mutation in position 167 of isotype $1 \mathrm{~b}-$ -tubulin gene of Trichostrongylid nematodes: role in benzimidazole resistance. Mol. Biochem. Parasitol. 120:297-300.

Thomaz-Soccol V.T., Souza F.P., Sotomaior C., Castro E.A., Milczewski V., Mocelin G. \& Silva M.C.E. 2004. Resistance of gastrointestinal nematodes to anthelmintics in sheep (Ovis aries). Braz. Arch. Biol. Technol. 47:41-47.

Torres-Acosta J.F.T. \& Hoste H. 2008. Alternative or improved methods to limit gastrointestinal parasitism in grazing sheep and goats. Small Rum. Res. 77:159-173.

Torres-Acosta J.F.J., Sandoval-Castro C.A., Hoste H., Aguilar-Caballero A.J., Cámara-Sarmiento R. \& Alonso-Díaz M.A. 2012. Nutritional manipulation of sheep and goats for the control of gastrointestinal nematodes under hot humid and subhumid tropical conditions. Small Rum. Res. 103:28-40.

Van Wyk J.A. 2001. Refugia-overlooked as perhaps the most potent factor concerning the development of anthelmintic resistance. Onderstepoort J. Vet. Res. 68:55-67.

Van Wyk J.A., Malan F.S. \& Randles J.L. 1997. How long before resistance makes it impossible to control some field strains of Haemonchus contortus in South Africa with any of the anthelmintics? Vet. Parasitol. 70:111122.

Van Wyk J.A., Bath G.F., Groeneveld H.T., Stenson M.O. \& Malan F.S. 2001. Wide testing of the FAMACHA system for accuracy of clinical evaluation of anaemia caused by Haemonchus spp. infection in sheep in South Africa. Proc. $5^{\text {th }}$ International Sheep Veterinary Congress, 22-25 Jan. 1993, Stellenbosch, South Africa, p.51-55.

Van Wyk J.A., Hoste H., Kaplan R.M. \& Besier R.B. 2006. Targeted selective treatment for worm management-How do we sell rational programs to farmers? Vet. Parasitol. 139:336-346. 